\title{
Transformation of the Accounting Profession in Terms OF THE ECONOMY OF THE FUTURE
}

\author{
Tetyana Slyozko ${ }^{1}$ [ Lyudmila Kurilo ${ }^{2}$; Oleksandra Mazina ${ }^{3}$ \\ ${ }^{1}$ Science and Research Institute of Social and Economic Development, \\ Golosiïvskiy, 98/2, of. 55; Kyiv, 03040, Ukraine \\ ${ }^{2}$ National University of Kyiv-Mohyla Academy, Faculty of Economic Sciences, \\ Department of Marketing and Business Management, \\ Skovorody, 2, Kyiv, 04070, Ukraine \\ ${ }^{3}$ University of the State Fiscal Service of Ukraine, Faculty of Economics, \\ Department of Accounting, \\ Universytetska, 31, Irpin, Kyivska obl, 08200, Kyiv, Ukraine \\ e-mail: ${ }^{1}$ t.slyozko@ukr.net; ${ }^{2}$ lyudmila.kurylo@gmail.com; ${ }^{3}$ oleksandra.mazina@ gmail.com
}

\begin{abstract}
This study examines the transformation of the accounting profession that will occur under the influence of the Fourth Industrial Revolution of the economy of the future. The presented paper firstly shows how the revolution may drastically change accounting as well as the accounting profession; secondly, the possibilities of accounting methods in accounting practice under the influence of the factors of the Fourth Industrial Revolution; thirdly, the robotization of accounting procedures; fourthly, accounting procedures the organization of which is not subject to robotics. Finally, despite significant changes in the accounting profession, it is proven that it will remain the same, especially in part of the organization's processes, since artificial intelligence or robotics cannot make managerial decisions on the organization of accounting apparatus, cannot perform certain accounting work and apply accounting methods in accounting processes.
\end{abstract}

\section{Keywords}

Accounting; Economy; Methods; Procedures; The fourth industrial revolution.

\section{Introduction}

The rapid development of the economy and society driven by the up-to-date computer technology and the most modern means of communication has paved the way for the Fourth Industrial Revolution that has occurred in the developed countries for several years. This revolution may drastically change accounting as well as the accounting profession. On the one hand, peculiarities of these changes consist in the important role of accounting as an information system, which collects and summarizes data on the economic activity of enterprises and growth of the economy. The accounting and it analytical function is performed through specific procedures and methods being inherent only to accounting such as documentation and stock-taking, valuation and calculation, accounts and double entry, a balance sheet and reporting. All these methods have a mathematical feature that has given them an opportunity to be subject to computerization, to function within any information technology, and, as a result, to provide transparent accounting information for any user. But, at the same time, the use of computers, robotics, and artificial intelligence may replace accountants. Consequently, this profession may be forced out from the labor market at all. 
Therefore, the question arises whether these changes will be a result of total victory of the Fourth Industrial Revolution in economies of all countries in the first and in the second cases. In this article, the authors search for an answer to the posed question.

\section{$1 \quad$ Research Objective}

The purpose of this article is to examine the influence of the Fourth Industrial Revolution or Industry 4.0 on importance of the accounting and analytical function of management in the process of formation of information for establishments and users, to indicate the role of the accounting profession under these new conditions related to rapid development of the economy of the future.

Obviously, the accounting is one of the most important instruments for managing social and economic systems, which consists in providing internal and external users with reliable and relevant information and is decisive for development of an economy and society. Meanwhile, industrial processes rapidly evolve. The Fourth Industrial Revolution, which is alternatively referred to as Industry 4.0, has been occurring for 5 years. Accounting is involved in this process. Applying the newest computer techniques and the most modern communication means, accounting adapts to online banking, online trade, electronic declaring and taxation, mobile payments, etc. Simultaneously, accounting remains a single system for formation of actual information on economic activity of enterprises, Fourth Industrial Revolution, and companies.

The accounting and analytical function of management enables to collect, register, specify, systematize, and generalize data, to transmit them to consumers in the form of various reports. Different types of accountants perform all these tasks. The Fourth Industrial Revolution constitutes a serious threat of job losses to accountants, as to other representatives of so-called "office plankton". Borg, A. [1] and Shvab, K. [2] consider the following threatening tendencies: an opportunity to work in any country without leaving home; an opportunity to work without presence at an organization or enterprise; an opportunity to plan working time independently; self-discipline; instability of incomes and absence of social guarantees, which will lead to demands for either highly qualified work and high salary or the low-skilled work and low salary (at the same time, middle class representatives, who include accounting staff, will be no longer required). What will happen to the accounting profession and the very accounting work, which has been performed by an accountant for many centuries? Search for an answer to the posed questions stipulates writing this article.

\section{$2 \quad$ Data and Methods}

To form an answer to the posed questions, there is a need to draw on at least two blocks of scientific research. The Fourth Industrial Revolution block encompasses publications, which allow defining the Fourth Industrial Revolution or Industry 4.0 and explain its main characteristics and consequences for the economy and society. This block includes scientific papers of foreign and Ukrainian authors, particularly Borg, A. [1], Shvab, K. [2], Dacin, M. T., Goodstein, J., Scott, W. R. [3], Dombrowski, U., Wagner, T. [4], Illiashenko, S. M., Illiashenko, N. S. [5], Kapoor, M. [6], Kontzer T. [7], Mikhailov O. M. [8], Opanasiuk A. S. [9], Pavlenko, A. [10], Skitsko, V. I. [11], Tantik, E., Anderl, R. [12], and others. The second block comprises scientific papers which examine issues concerned with formation of accounting information and also the socio-economic Institute, through which Regulation of enterprises' activities is carried out. Let's add some more publications that we have recently seen: Brandas, C., Megan, O., Didraga, O. [13], Trigo, A., Belfo, F., Estébanez, R. P. [14], Burns, J., Scapens, R. W. [15], Zuk, V. M. [16]. There are dozens of such papers. The authors of this article have studied the mentioned papers for years. Nevertheless, neither of these 
scientific papers discloses the role of the accounting institution and the accounting profession in the economy under conditions of the Fourth Industrial Revolution. This idea has become subject to research in this article.

\section{The Main Research Results}

Primarily, it is important to get acquainted with the very notion of this revolution, which occurs in the most developed world economies, particularly in the USA and Germany, and is forced by large industrial companies and scientific centers in order to attain the objectives mentioned by Skitsko, V. I. [11]. Professionals assert that the Fourth Industrial Revolution is a result of implementation of new information and communication technologies in the economy. These processes have the greatest influence on the representatives of accounting, which occupy an important place in the management system. There are five functions of management business functions: planning, accounting, analysis, regulation and controlling. The function of accounting, the function of control and the analysis function are often performed by accountants. It is precisely in front of accountants that the Fourth Industrial Revolution poses a difficult problem: will they remain in the future economy? It is also noticeable for tendencies which will significantly affect the profession of accounting professionals. The tendencies concerned with a labor market were outlined above. However, there are other tendencies and issues that will be discussed next in this study.

\subsection{Trends in Scientific Literature and in Theory}

In general, literature sources propose to divide the main tendencies of the Fourth Industrial Revolution into the following groups: a) development of technologies of customer experience management; b) transition from mass production of the same products to "mass customization" (mass production of individual orders); c) "glocalization" is substituted for globalization, i.e. "think globally - act locally"; d) development of technologies such as The Internet of Things (IoT); e) an opportunity of remote control for everything, including production; f) 3D-print; g) smart objects, smart devices, smart sensors; h) performing works at home, i.e. development of automatization and robotization eliminate advantages of labor resource cheapness; i) adherence to global standards becomes necessary and obligatory even in local markets; j) stable development and growth of a population, an economy, science, technologies on the one hand and steadily increasing ecological problems on the other hand Mikhailov, O. M. [8].

Illiashenko, S. M. and Illiashenko, N. S. [5] in their work "Prospects and threats to the Fourth Industrial Revolution and their taking into account when choosing strategies for innovative growth" point to the Fourth Industrial Revolution as complete fifth technological ways and the beginning of the transition to the six ways (2020-2025 years). This way - they point out it is in those countries that have a powerful research, education and intellectual potential, entrepreneurs and professionals that are able to quickly adapt, learn and retrain, use their knowledge and ability to realize themselves in the new environment. These are the promising directions, which are already forming and will continue to form the sixth technological way. They basically divide it into two blocks: the first is all new technologies and materials, which have arisen and continue to arise and actively disseminate and develop; the second is all the innovations that are directly related to the person, their role and meaning in this world. Above all they conclude there should be a new, more advanced intelligence for the transition to advance development. It is the source and mechanism of advanced development and it includes: biotechnology and nanotechnology, genetic engineering, ecotechnology, information technology, laser technology, a new level of the educational system, artificial intelligence, production "without people" and robotics [5]. All these factors significantly 
influence the profession of an accountant since all modern accounting has been translated into the latest information technology. This trend extends to practice today, which will be discussed later in this article.

\subsection{Trends in Practice of Accounting}

A majority of these tendencies are related to accounting because it performs the function of a registrar for all occurring economic transactions (processes of sales in trade, the inflow or outflow of material and financial resources, production and distribution, wage payment, determination of costs and results of activity, etc.). The accounting system prepares information for interested users: institutions (authorities of fiscal services, banks, statistics services, social insurance funds); owners, creditors, counteragents, managerial staff, enterprise employees and auditors. They gain this information in the form of different types of statements (financial, tax, statistic, and managerial), preparation of which is regulated by higher institutions (legislative and executive) that establish rules and requirements to record keeping. These requirements are simultaneously requirements to business. Therefore, the accounting and analytical support of enterprise activity becomes an instrument for the regulation of this business.

It is through the informational capabilities of accounting that correct application by the entrepreneurs of the "rules of the game" can be checked, which are set by the institutions as a requirement for accounting. Based on these rules, it must provide accounting information compliance with the requirements, which have been established by institutions (financial, taxation) - in various types of reports. This is due to the fact that only in the system accounting is registered and accumulates all the information about the assets and liabilities of the enterprise, business transactions with them every day in the mode of its continuous display in the calendar sequence with the help of special methods. There are eight or alternatively four binaries: documentation and inventory, evaluation and calculation, accounts and double entry, balance summarizing and reporting.

These methods emerged more than five hundred years ago (the Fourth Industrial Revolution treatise on the accounts was published by Luca Pacioli in 1494) and turned out to be so mathematical (accounts, double entry, an accounting balance sheet) that were amenable to contemporary programming. This enabled to translate manual accounting in the machinery language more than 60 years ago. Nowadays, accounting information is promptly transmitted through the Internet. This allows controlling transactions of any enterprise in the online regime. Modern programs for automatization of accounting facilitate such processes. Due to this, accounting methods can be performed by artificial intelligence under the conditions of the Fourth Industrial Revolution, which will be considered further more.

\subsubsection{Opportunities of the Methods of the Accounting in Accounting Practice under the Influence of Factors of the Fourth Industrial Revolution}

It should be noted that among the methods mentioned above in this study, part of them in terms of the Fourth Industrial Revolution will be completely robotical while others will survive, however, in a revised form. So, today there are two pairs of methods fully computerized: accounts and double entry, balance summarizing and reporting. However, the first two pairs of methods by any conditions of informatization and robotics cannot be carried out without an accountant.

The first and second methods are carried out only with the participation of responsible persons - accountants or inventors. This situation is due to the fact that in the first case, the primary documents are formed only if concrete persons (legal or physical) enter into a 
contract between themselves for the implementation of a particular business transaction. Under the inventory method, the transfer of values should also be carried out only under the control of a representative of the management apparatus, including a representative of the accounting department. The same situation applies to the following two methods - estimation and calculation. Here it is also possible to estimate or calculate the cost of objects only by a specialist, who inspects and measures a particular object, determines the level of fitness, etc. Of course, robotics still cannot perform such functions.

For example, in respect of such an element of the accounting method as valuation, accountants conduct valuation with regard to intangible assets (know-how, patents, trademarks (a brand), design patents, software, information and software, means of communication and connection, managerial technologies) through a procedure of testing under conditions of information technologies. Owing to information systems of technology transfer and information resources, accountants exercise quantitative and qualitative valuation (of capitalization opportunities) of inventories, development results, ideas and other types of intellectual assets, using access to the Internet. In the process of positioning of the mentioned assets in such information systems, experts gain results of testing being analogues of results of sociological surveys and expert estimation with elements of the recommendation method. Such operations can perform only specialists (accountants or appraisers) but not artificial intelligence or robot. In all cases, accounting will always have the important place of a registrar of transactions and objects at an enterprise. For this accounting has not only special methods, as discussed above, but also a set of special procedures.

\subsubsection{Robotization of Accounting Procedures}

Before evaluating accounting procedures in terms of robotizing, let us look at ourselves. These are the procedures with the use of which a consistent display of objects and business processes "from of a balance sheet and to a balance sheet" is affected. In general, it is this sequence that is called an accounting procedure or an accounting process. It is a sequential execution of the following procedures: (a) opening of accounts on the ledgers, automatically or manually; (b) registration of transactions or business operations in them using the double entry method; (c) posting of these operations is done on synthetic and analytical accounts between which (d) double-entry control is carried out. Based on the above, we come up to approach the summing up, that is, drafting of a trial balance sheet. Before this or parallel is carried out closing of individual accounts. Thus, accounting procedures end in drafting of a balance sheet and reporting.

To launch the process of collection, registration and organization of information, all of these procedures should be organized, in particular, the following must be carried out: (1) organization of documentation of business operations; (2) organization of data processing, recorded in primary documents; (3) organization timely and accurate display of all transactions on the ledger accounts in order to generate reports; (4) organization work of Accounting Department and of its staff; (5) organization complex collaboration of employees of the accounting department with other units (financial, planning, monitoring, analytical) and with other centers of responsibility. From what was shown above, we will try to find out which procedures can be performed by artificial intelligence, and which will remain under the guidance of accountants. It should be noted that almost all of these procedures can be performed by artificial intelligence. To implement these steps already today there are the following information resources which will significantly save time (money) and help to verify an idea or prototype: BetaList, Javelin Experiment Board, QuickMVP. However, organization procedures will be not performed by artificial intelligence because the organization is carried out by people - in this case, accounting officers. 


\subsubsection{Procedures of Accounting the Organization of which Is Not Subject to Robotics}

Let us begin with the concept in which the organization of accounting defined as a set of actions to create an integrated accounting system, the functioning of which is aimed at ensuring the information needs of users of accounting information. The key words here are: the organization, set of actions, creation. That is, work (human or machine) can be organized only by person who does some action or set of actions. In our case - an organization of actions aimed at collecting information, its verification, accounting processing, generalization and systematization and interpretation for the requirements of users. In the practice of business all these actions are organized by the representatives (subjects) of management.

In the organization of accounting, representatives (subjects) of this organization are the leaders of the enterprise (company) - the director and the chief accountant, who are responsible for accounting and provision made by fixing all business transactions in the primary documents, saving documents processed, registers and reports within the prescribed period, but not less than three years. In the first place, such responsibility is assigned to the owner (owners) or the authorized body (official), who now manages in accordance with the law and founding documents. Here we see another keyword - the responsibility - that can only be borne by people, not by machines or robots. The next keyword is the method of organization - it is the ways and methods in which there is an organization of accounting process, including the construction of financial services, the development of different kinds of charts of accounts made to work (document management, inventory, information about completed registration in the lower levels of the higher links of others).

The whole organization of accounting would be nothing if it was not subordinated to any particular purpose. Therefore, here the next key word becomes the purpose. That the purpose of accounting management system now is to prevent undesirable outcomes and impacts of its operations on the basis of timely recording of all business transactions that occur on it continuously flowing internal controls and a generalization for reporting. From this it can be seen that a robot cannot give the purpose of the organization of accounting work, because it is what only people can, in our case, this is done by people, in particular, the company's accounting and management staff. However, in any case, the continuous computerization of accounting and the use of artificial intelligence in it, under the guidance of the representatives of the accounting apparatus, are now helping to combat the shadow economy.

\section{The Computerization of Accounting and the Use of Artificial Intelligence - Accounting Becomes an Obstacle Restraining the Grey Economy}

Owing to such an approach to creation of information, accounting becomes an obstacle restraining the grey economy. This will enable to undertake one of the most important economic reforms, which consists in ensuring transparency of data at all stages of creation of the social product: production, exchange, distribution, and consumption. To achieve this objective, all economic transactions should be carried out exclusively in the non-cash form. Such payments will allow accountants to register operations in the regime of transparency. In addition, this regime should be concerned with enterprises as well as citizens all the more so because all of them obtain salary, pensions, and social aids through banking cards. Banking cards have to become a single means for payments, including in retail trade, at enterprises of a foodservice sector, and providing services. Any payment for goods or services at these enterprises will pass through special terminals for card payments and cash registers.

Medvedev, M. [17] has proposed a complex of procedures based on a computer form, which will assist to implement this reform, which encompass a computer network, cessation of cash transactions, registration of legal entities, operational databases, necessary technical 
equipment, consolidation of balances, cancelation of a commercial secrecy, registration of agreements (contracts), control over performance of agreements, registration of conditional agreements, termination of agreements, declaring a commodity price, penalties, conditional obligations, responsibility for non-optimal purchase, taxation, cessation of legal entities, a profession [17, pp. 679-714].

In addition, experts prognosticate that application of Bitcoin digital currency and blockchain [18], [19] technology for tracking transactions and management of distributed databases will guarantee absolute transparency of the data. In terms of these technologies, an accountant will use a common ledger, which may not be "configured" by efforts of one person. The experts think that governments may begin to use blockchain technology in the process of tax collection in 2023. In 2025, approximately $30 \%$ of corporate auditing will be conducted, using maximally unbiased artificial intelligence [20,21].

Thus, transformations of accounting and analytical function of management occur under conditions of development of knowledge economy and an information society. What's going on with the accounting profession? An answer is disappointing. The profession is influenced by serious changes. These changes have begun with automatization of accounting, when the Fourth Industrial Revolution programmer appears. Nowadays, the profession falls into two professions: a programmer and an accountant. The former translates knowledge from accounting to the machine language, creating software. The latter types data and a computer program automatically registers facts of economic activity, details, and systematizes them, generalizing in various types of statements at request of different users.

Due to the mentioned reasons, a modern accountant turns into an operator. At the same time, a programmer is an expert in accounting methodology. Under conditions of entire automatization of collection of accounting information at the moment of economic operation execution, its automatic transmission to a single processing center, application of artificial intelligence, mobile communication, cloud technologies, and applications for mobile phones at these stages, when there is a need only for a special terminal on the way out, which will withdraw a corresponding amount with a telephone, an enterprise does not even need an operator.

Obviously, that accountant, who works at an enterprise now, will not exist in the future economy. New specialists, who will respond to demands of a labor market of the future economy, will replace an accountant. Possibly, a particular part of accountants will try to study programming, becoming a programmer and accountant simultaneously. Nevertheless, real programmers will force them out from the labor market. A particular part of the profession will remain in the form of professional accountants, auditors, and financiers. However, their functions may change because there is demand for financial analysts and accounting analysts at large companies and Fourth Industrial Revolution.

Completely new professions, namely an accounting notary and creative accountant, will supplement a noted list. The above mentioned Medvedev, M. [17] has proposed them for the Fourth Industrial Revolution time. In the chain of automatic collection of accounting data, the accounting notary will have to conclude typical and especially non-typical agreements. Institutions of law do not precisely define the very non-typical agreements. Nevertheless, nontypical agreements should become an accounting entry. Thus, accounting notaries (as a disinterested party) can exercise this right [18, p. 712]. Creative accountants will implement creative accounting, which will prognosticate achievements of an enterprise in the economic life. Consequently, the accounting profession under the influence of the Fourth Industrial Revolution tendencies is modifying and will exist in an updated format in the immediate future as can be seen in Figure 1. 


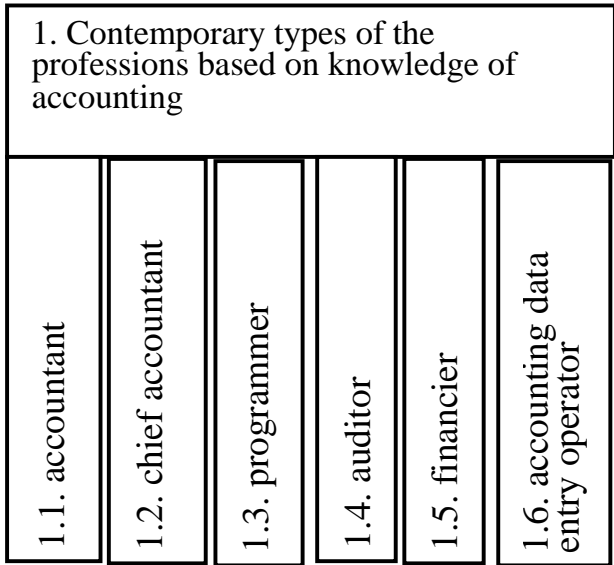

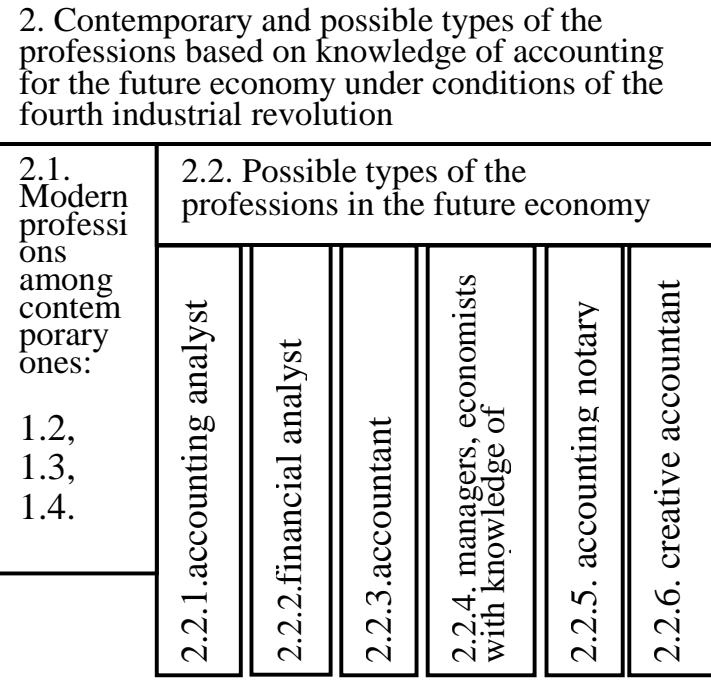

Source: Own development of the authors

Fig. 1: Variety of the accounting profession in the contemporary and future economy

\section{The Systematization of Accounting Professions in Modernity and in the Future Economy}

In Figure 1 the accountant profession is divided into two groups: the first one, the Fourth Industrial Revolution, comprises modern types of the profession based on accounting knowledge; the second one comprises modern as well as possible types of the profession, which will draw on the knowledge of accounting. Current and future needs for knowledge of accounting stipulate such systematization. Even the most contemporary technical means will not collect, systematize, and detail information on activity of an enterprise without usage of accounting methods, procedures, and principles in the process of software program creation.

Therefore, the future of the accounting profession implies its entire modification, which Fourth Industrial Revolution constitutes absorption by other professions as happened with an auditor or a financier. In western society auditors have existed for many decades (more than 15 years in our country). They are the best experts in accounting because their task consists in verification of accounting. The same can be said about a financier, functions of whom chief accountants of enterprises or their deputies have performed. They have provided the entire procedure of accounting "from a balance sheet to a balance sheet".

In terms of the Fourth Industrial Revolution, this procedure will be in an integrated database of accounting data, which can be a source of any information at any time. Nevertheless, users should be able to extract and use such information. In the future economy, experts of any economic sphere can become these users, e.g. various managers and economists, who have to analyze activity of their departments or units of management. To achieve this goal, they should be aware of a program algorithm as well as the main principles and methods of accounting in order to find the beginning of creation of information and to understand why a result is as it is and not another.

\section{Conclusion}

The outlined assertions have enabled to draw the following conclusions. The Fourth Industrial Revolution, the accounting and analytical function under conditions of information 
technologies of the Fourth Industrial Revolution remains an important instrument for providing users with necessary information on the state and development of economic systems. The mathematical component of accounting performs this function despite the development of social and economic relations and changes in a society.

Secondly, the accounting profession will be significantly modified under the influence of the new revolution. Obviously, the profession of an accountant in the contemporary form will disappear in the labor market. It will be most likely absorbed by other professions which need the knowledge of accounting. These professions encompass programmers, auditors, analysts, financiers, economists, managers, financial analysts, accounting notaries, and creative accountants.

Thirdly, in spite of the significant transformations of the profession of an accountant, the profession will remain the same, especially in part of the processes of the organization, because artificial intelligence or robotic cannot accept managerial decisions on the organization of the accounting apparatus and the performance of certain accounting work, the application of accounting methods or accounting processes. Such specific actions can only be performed by people. These people are the organizers of accounting.

Since issues of the role of accounting in the future economy, which will emerge owing to the Fourth Industrial Revolution, and the importance of the profession of an accountant in the future are new, the questions posed in this article will provoke a lot of discussion. This stipulates the necessity to conduct new research of this subject.

\section{Literature}

[1] BORG, A.: How will the Fourth Industrial Revolution affect economic policy? [online]. 2016. Available from WWW: https://www.weforum.org/agenda/2016/01/how-will-thefourth-industrial-revolution-affect-economic-policy. Russian translation available from WWW: $\quad$ http://hvylya.net/analytics/economics/vliyanie-chetvertoy-industrialnoyrevolyutsii-na-ekonomicheskuyu-politiku.html

[2] SCHWAB, K.: The Fourth Industrial Revolution: Challenges and opportunities. [online]. 2016. Available from WWW: https://techinsight.com.vn/language/en/fourthindustrial-revolution-challenges-opportunities-part-1/, https://techinsight.com.vn/language/en/fourth-industrial-revolution-challengesopportunities-part-2/ Russian translation available from WW: https://hvylya.net/analytics/society/chetvertaya-industrialnaya-revolyutsiya-vyizovyi-ivozmozhnosti.html

[3] DACIN, M. T.; GOODSTEIN, J.; SCOTT, W. R.: Institutional Theory and Institutional Change: Introduction to the Special Research Forum. The Academy of Management Journal. 2002, Vol. 45, Issue 1, pp. 45-56. DOI: 10.2307/3069284. Available from WWW: https://www.jstor.org/stable/3069284

[4] DOMBROWSKI, U.; WAGNER, T.: Mental Strain as Field of Action in the 4th Industrial Revolution. Procedia CIRP. 2014, Vol. 17, pp. 100-105. DOI: $\underline{\text { 10.1016/j.procir.2014.01.077 }}$ 
[5] ILLIASHENKO, S. M.; ILLIASHENKO, N. S.: Перспективи і загрози Четвертої Промислової Революції та їх урахування при виборі стратегій інноваційного зростання (Prospects and threats to the Fourth Industrial Revolution and their taking into account when choosing strategies for innovative growth). Маркетинг $i$ менеджмент інноваиій (Marketing and management of innovations). [online]. 2016, Issue $1 . \quad$ Available from http://mmi.fem.sumdu.edu.ua/sites/default/files/mmi2016_1_11_21.pdf

[6] KAPOOR, M.: Redefining Progress and Ushering in the Fourth Revolution. Procedia Social and Behavioral Sciences. 2014, Vol. 133, pp. 203-210. DOI: $10.1016 /$ j.sbspro.2014.04.185

[7] KONTZER, T.: Robots Take Over the World! Not Such a Crazy Fear. Investor's Business Daily News. [online]. 2015. Available from WWW: http://news.investors.com/technology/031315-743468-ai-warnings-from-hawkingmusk-gates-taken-to-heart.htm\#ixzz3YyS

[8] MIKHAILOV, O. M.: Industry 4.0 - $4^{\text {th }}$ industrial revolution. [online]. 2016. Available from WWW: http://appau.org.ua/Indusrty_4-0-4_Idustry_revolution

[9] OPANASIUK, A. S.: The third and fourth technological revolution. [online]. 2016. Available from WWW: http://rcrs.sumdu.edu.ua/images/pic/new-4.pdf

[10] PAVLENKO, А.: Револючия 4.0: Какой будет новая промышленная революиия и что она принесет развитым странам (Revolution 4.0: what will be the new industrial revolution and that she will bring to developed countries). [online]. 2016. Available from WWW: http://delo.ua/world/revoljucija-40-kakoj-budetnovajapromyshlennaja-revoljucija-i--311090

[11] SKITSKO, V. I.: Індустрія 4.0 як промислове виробництво майбутнього (Industry 4.0 how industrial production future). [online]. 2016. Available from WWW: http://www.investplan.com.ua/pdf/5_2016/8.pdf

[12] TANTIK, E.; ANDERL, R.: Industrie 4.0: Using Cyber-physical Systems for Valuestream Based Production Evaluation. Procedia CIRP. 2016, Vol. 57, pp. 207-212. DOI: $\underline{10.1016 / j . p r o c i r .2016 .11 .036}$

[13] BRANDAS, C.; MEGAN, O.; DIDRAGA, O.: Global Perspectives on Accounting Information Systems: Mobile and Cloud Approach. Procedia Economics and Finance. 2015, Vol. 20, pp. 88-93. DOI: 10.1016/S2212-5671(15)00051-9

[14] TRIGO, A.; BELFO, F.; ESTÉBANEZ, R. P.: Accounting Information Systems: Evolving towards a Business Process Oriented Accounting. Procedia Computer Science. 2016, Vol. 100, pp. 987-994. DOI: 10.1016/j.procs.2016.09.264

[15] BURNS, J.; SCAPENS, R. W.: Conceptualizing management accounting change: an institutional framework. Management Accounting Research. 2000, Vol. 11, Issue 1, pp. 3-25. DOI: $10.1006 /$ mare.1999.0119

[16] ZHUK, V.: Scientific Grounds for Brand New Institutional Accounting Theory. Accounting and Finance. 2013, Issue 3, pp. 29-34. Available from WWW: https://econpapers.repec.org/article/iafjournl/y 3a2013 3ai_3a3 3ap_3a29-34.htm

[17] MEDVEDEV, M.: Total accounting theory: natural, accounting and computer methods. Business and service, 2001. 752 p. 
[18] NAKAMOTO, S.: Bitcoin: Bitcoin: A Peer-to-Peer Electronic Cash System. [online]. 2014. Available from WWW: https://bitcoin.org/bitcoin.pdf. Russian translation available from WWW: https://habrahabr.ru/post/215557/

[19] TAPSCOTT, D.; TAPSCOTT, A.: SXSW Preview: What's the Next Generation Internet? Surprise: It's all about the Blockchain! [online]. 2015. Available from WWW: https://www.linkedin.com/pulse/whats-next-generation-internet-surprise-its-alldon-tapscott

[20] NOVE.TODAY.: Технологические достижения, которые мы увидим к 2030 году (Technological advances, which we see to the year 2030). [online]. 2016. Available from WWW: http://nove.today/posts/tehnologicheskie-dostizheniya-kotorye-myuvidim-k-2030-godu-newsyou

[21] DIRICAN, C.: The Impacts of Robotics, Artificial Intelligence on Business and Economics. Procedia - Social and Behavioral Sciences. 2015, Vol. 195, pp. 564-573. DOI: $10.1016 /$ j.sbspro.2015.06.134 


\section{TRANSFORMACE ÚČETNÍ PROFESE V EKONOMICE BUDOUCNOSTI}

Tato studie zkoumá transformaci účetní profese, ke které dojde pod vlivem čtvrté průmyslové revoluce ekonomiky budoucnosti. Tento článek nejprve ukazuje, jak může revoluce drasticky změnit účetnictví a účetní profesi; za druhé, možnosti účetních metod v účetní praxi pod vlivem faktorů čtvrté průmyslové revoluce; za třetí, robotizaci účetních postupů; za čtvrté, účetní postupy, jejichž organizace nepodléhá robotice. Nakonec je prokázáno, že navzdory významným změnám $\mathrm{v}$ účetnictví zůstane toto povolání stejné, zejména $\mathrm{v}$ rámci procesů organizace, protože umělá inteligence ani robotika nemohou přijímat manažerská rozhodnutí o organizaci účetnického aparátu, provádět určité účetní úkony či aplikovat účetní metody $\mathrm{v}$ účetních procesech.

\section{TRANSFORMATION DES BERUFS DES BUCHHALTERS IN DER ÖKONOMIE DER ZUKUNFT}

Diese Studie untersucht die Transformation des Berufes des Buchhalters, zu welcher es unter dem Einfluss der vierten industriellen Revolution der Zukunftsökonomie kommt. Dieser Artikel legt als Erstes dar, wie die Revolution das Rechnungswesen und die Profession des Buchhalters auf drastische Weise verändert, als Zweites die Möglichkeiten der buchhalterischen Methoden in der Buchhaltungspraxis unter dem Einfluss der Faktoren der vierten industriellen Revolution. An dritter Stelle wird die Automatisierung der buchhalterischen Vorgehensweisen gezeigt und an vierter Stelle werden diejenigen buchhalterischen Vorgehensweisen dargelegt, deren Organisation nicht der Automatisierung unterliegen. Schließlich wird bewiesen, dass trotz beträchtlichen Veränderungen im Rechnungswesen diese Profession gleich bleibt, da weder die künstliche Intelligenz noch die Robotik Managerentscheidungen hinsichtlich der Organisation des Buchhaltungsapparates zu treffen noch gewisse buchhalterische Handlungen vorzunehmen noch die Buchhaltungsmethoden in den Buchhaltungsprozessen anzuwenden im Stande sind.

\section{TRANSFORMACJA ZAWODU KSIĘGOWEGO W GOSPODARCE PRZYSZŁOŚCI}

Niniejszy artykuł ma na celu zbadanie transformacji zawodu księgowego, jaka nastąpi pod wpływem czwartej rewolucji przemysłowej gospodarki przyszłości. W pierwszej kolejności pokazano, w jaki sposób rewolucja może drastycznie zmienić rachunkowość i zawód księgowego, następnie przedstawiono możliwości metod księgowych w praktyce rachunkowości pod wpływem czynników czwartej rewolucji przemysłowej; po trzecie uwagę skupiono na robotyzacji sposobów księgowania a po czwarte zaprezentowano zadania księgowe, których organizacja nie podlega robotyzacji. W zakończeniu udowodniono, że pomimo znacznych zmian w rachunkowości zawód ten zostanie niezmienny, w szczególności W zakresie procesów organizacji, ponieważ sztuczna inteligencja ani robotyka nie mogą podejmować decyzji zarządczych o organizacji systemu rachunkowości, dokonywać pewnych czynności księgowych czy stosować metod rachunkowych w procesach księgowych. 